\title{
Reflecting on criminalizing male violence against women under human rights and human security discourses: a feminist legal and policy analysis
}

\author{
${ }^{1}$ University of Padova, Padua, Italy, E-mail: claudia.pividori@unipd.it, paola.degani@unipd.it
}

\begin{abstract}
:
Violence against women is an established issue of concern under international law as well as in the international security domain. More in general, it is contended that issues related to gender-based violence need to be countered with strategies aimed at fighting sexual hierarchies and structural discrimination affecting women at different levels and in different contexts. Despite this, international legal and policy responses to male violence against women are increasingly turning to criminal law enforcement with a strict focus on perpetrators' individual accountability. The article critically analyzes this trend within the two international legal and policy frameworks that in the past decades have most consistently integrated the issue of violence against women, that is, human security and human rights. The article contends that the increasing focus on criminalization that has emerged in both these frameworks risks obfuscating and downsizing the collective and "public" dimension of States' responsibility with regards the social phenomenon of violence. Indeed, criminalization strategies allow States to circumvent their duty to work on the social, political and economic structural dimensions at the root of this severe form of violation women's human rights.
\end{abstract}

Keywords: feminist legal theory, women's human rights, gender security, violence against women, international politics

DOI: $10.1515 / g j-2017-0028$

\section{Introduction}

In the last two decades, international legal and policy responses to the social phenomenon of male violence against women has focused, on the one hand, on women's victimization - and therefore also on the progressive criminalization of acts of violence; on the other hand, on women's empowerment, agency and participation. Adopting a policy framework analysis, the aim of this paper is to analyze the different orientations adopted within the human rights and human security frameworks with regards to the issue of male violence against women as a result, in particular, of the recognition and consolidation of a gender perspective in the security discourse developed by feminist approaches to International Relations and International Law (Bunch and Reilly 1994; Shepherd 2010; 2008b).

Feminist research has provided a more in-depth reflection on the social construction of women's vulnerability in the context of gendered social hierarchy, where the social values associated with femininity and masculinity perpetuate inequality (Tickner 1992 1995). Undoubtedly since the 1990s the international community has looked at the issue of male violence against women, both in peacetime and in conflict-related scenarios, differently than before. In the first case, by recognizing it as a social phenomenon linked to discrimination and inequality on the basis of sex. In the second, by characterizing it as a gender-related security issue to be addressed according to the human rights paradigm. Beside this institutional commitment, feminist research in the area of international relations and international law has worked to bring a gender perspective to the issue of security, taking on with vigor the problem of male violence against women, its meanings and pervasiveness (Charlesworth, Chinkin, and Wright 1991; Edwards 2010; Tickner 1992; 1995; Youngs 2008).

Such development has highlighted the need to develop a women's point of view from a critical normative analysis of gender inequality (Baxter and Lansing 1980; Shepherd 2010). Feminist research has emphasized the need to identify a balanced and holistic political and legal response to it and thus take advantage of the perspectives offered by human rights law to combat the social phenomenon of violence (Bunch 1990; Chalresworth and Chinkin 2000). That is, first of all, by addressing women's economic and social disadvantages, and working on a new conceptual and material perspective of peace and security (Boserup 1970; Reardon 1985; Brock-Utne 
1989). This approach calls for a move that goes beyond an international relations discourse oblivious of gender. On the contrary, it aims to bring women's lives to the center, for the recognition of women's subordination, and the traditional dual gender dichotomy inside/outside and public/private (Sullivan 1995; Radačić 2007).

Notwithstanding these conceptual and policy developments, the international legal and policy response to male violence against women is increasingly turning to criminal law enforcement from a structural perspective. After introducing some consideration on the re-conceptualization of male violence against women from a feminist perspective, the article presents and critically analyzes this trend within the two international legal and policy frameworks that in the past decades have most consistently integrated the issue of violence against women: human security and human rights. It starts with a discussion on the progressive emergence and consolidation of punitive options as the response to women (in)security. Then, it elaborates on the increasing reliance of international human rights law on criminalization strategies. Building on these two sections, the article addresses the merits and limits of criminalizing male violence against women. It is suggested that such trend, on the one hand, emphasizes the victimization of women rather than portraying women as agents of change and, on the other, it fails to grasp the structural character of violence against women.

In conclusion, the article contends that, while representing a fundamental step in framing male violence against women as a serious violation of individual rights, criminalization strategies need to be framed within a broader political and legislative scenario able to propose an authentic feminist perspective on gender and human security (Hudson 2005; Kirby and Shepard 2016).

\section{Male violence against women: introductory considerations}

The issue of male violence against women has become crucial in the current debate on women's security and human rights for a number of reasons correctly identified by feminist literature. The fundamental assumption derives from the recognition that the female condition, provided the necessary distinctions in term of nationality, religion, social status, age, presents to a considerable extent a series of universalizing characters due to women's primary involvement in caring and domestic work. This consideration, while not certainly justifying the existence of a feminine essence, makes the condition of women a cross-cutting issue.

With regard to male violence, it is quite evident that women, while experiencing different forms and practices of violence, share the same experience of subjugation and inequality. This assumption is crucial in order not to be tempted by essentialist arguments about women, but also to emphasize the importance of looking at every woman individually because all people, all women experience gender in a different way. Women are subjected to discrimination and violence in ways that often do not affect men. To a significant extent, abuses and violations against women are of sexual or reproductive nature. Otherwise, they take place in environmental or relational contexts which mark, both on a material and symbolic level, the bond between the female condition and women's reproductive function, its gratuity and its invisibility, as well as the division between the personal and the "political" that obscures the suffering of many marginalized people.

Only from the assumption of the ordinary dimension of women's discrimination and subjugation can the intersection of women's life experiences before, during and after humanitarian emergencies be explained. During conflicts and emergencies women face social and economic problems that increase their vulnerability. For many women, the relationship between the physical violence experienced during conflict and the security of the post-conflict environment are not discontinuous realities. Yet, they are part of a singular experience defined by discrimination and abuses rooted in the cultural and social context of many of the countries involved in situations of emergencies and transition (Giles 2004; Degani 2014).

Gender dualism (the division between male and female) is firstly characterized by hierarchies rooted, to various degrees of depth, in the various social and cultural contexts. The issue of women's equality reflects this complexity as the forms of discrimination that still affect women make them more vulnerable to living conditions that are incompatible with the very idea of "human security" and "human rights" (Fineman 2008). Indeed, numerous emergencies have recently created the conditions to develop greater awareness on the issue of women's "insecurity". Such emergencies also include the recent and on-going economic crisis, even in European countries. Moreover, today's migration processes increase and trigger political contradictions that many States face: changes affecting labor relations; female migration in its different expressions; trafficking of young women for sexual exploitation and the proliferation of sex business on an industrial scale; the spread of ethnic conflicts; ideological and religious fundamentalisms; the visibility of male violence as a social reality transversally adds up to all the other peculiarities that might characterize women's condition (Sjoberg 2006).

Such situations of crisis during the last 20 years have brought about a radical change in the way women's security and the reality of women's life is considered. In times of conflict, the need to prohibit a series of conducts, now recognized by international criminal law as crimes against humanity, war crimes or even genocide, 
has been formally acknowledged. In times of peace, the feminist concept of violence as well as its causes have been re-thought as social phenomena in relation to which the public and the private dimension intermesh and influence one another, both at a level of values (symbolic dimension) and on a material dimension (Pickup, Williams, and Sweetman 2001; Goldstein 2001).

\section{Re-conceptualizing women (in)security}

For over two decades, feminist IR studies, especially feminist security studies, have successfully challenged the traditional notion of security (Shepherd 2008a; Sjoberg 2009). In the feminist security tradition, women's insecurities are understood as immediate and long-term threats to women's lives, both considered to result from established and unjust power relations between women and men (Jansson and Eduards 2016). More specifically, feminist theory adopts an analytical approach on international relations based on gender and equality which considers male violence against women as an issue strictly related to security, both in times of peace and armed conflict, overcoming the idea that the only type of security that matters is state security (Elshtain 1987; Bethke and Tobias 1990).

Traditionally, many international relations theories revolve around the analysis of state relations, with particular emphasis on war, security, economic, financial and macroeconomic management (Steans 1998; Kehoane 1989). The feminist theory in international relations started from criticism to the basic assumptions of realism and liberalism in different ways (Tickner 1988). Today the role of women, and more specifically the relevance of a gender perspective, has acquired great importance in most of the humanities and the social sciences literature, overcoming the blindness that for long has pervaded most international relations studies and thus giving visibility to the gender-specific consequences of international processes (Enloe 1993).

Feminism has challenged traditional realist views of power and the implications of power in an anarchical world, arguing that this perspective overvalues the role of the states in defining international relations, without debating on how the state itself is internally structured as well as politically and socially organized (Tickner 1995; 2001; Kehoane 1989). A significant first distinction in terms of feminist theory to the traditional approaches to international relations is represented by the need to consider how the state "includes" or "excludes", in terms of nationality, citizenship and welfare, and how, in turn, the state's domestic position translates it into foreign policies (Yuval-Davis 2008). Furthermore, feminist theories, looking at women's condition in domestic and foreign politics and policies, have long considered that international relations have been and still are primarily based on male patriarchal background in both political activities and research fields. Feminist academics often point to patriarchy and militarism as social systems that contribute in reproducing socially constructed gender norms and roles (Enloe 2000 2007). Patriarchy is viewed as a social system that legitimizes domination of men over women, while militarism is understood as a social system that legitimizes dominance of military over civilian populations and justifies the use of violence to resolve conflicts. Both patriarchy and militarism are based on notions of masculinity and manhood that encourage men to wield power, to take up arms and defend those in need of protection (Whitworth 2004). They also divide the population in two groups, the protectors on the one side (with a license to use violence) and those in need of protection on the other side.

While historical theories of realism and liberalism tend to get much of the attention when explaining the relations within the world we live in, feminism in both international relations and international legal theory has attempted to provide a new, yet equally important voice to issues that are directly related to the quality and the rights of people, making specific reference to equality based on sex and gender. Starting the analysis from gender inequality in unpaid care-work and the related economic subordination helps explaining the different missing links that influence gender gaps in different societal, political and economic contexts as well as contextualizing male violence against women within a political economy perspective (Armstrong, Walby, and Strid 2009; Verloo 2007). In shedding light on the inequalities that women normally experience, feminist analysis has exposed the forms and scale of women's human rights violations. In this sense, given the specific nature of certain risks affecting the status of women, as well as the total neglect of women's needs by traditional models of security, violence against women could very well prove to be the turning point between male and female (in)security.

While for a long time feminist movement have been unable to structure a gender-inclusive discourse within realist security studies, during the 1990s, when a more person-oriented concept of security emerged, it became easier to think about "new" or "different" states of insecurity (Tickner 1992). In this connection, after women's groups had lobbied for years to place women's issues high on the political agenda, it was only when the concept of human security, advanced by the United Nations Development Program (UNDP) in 1994, in the 5th Human Development Report, ${ }^{1}$ that gender security had become relevant (Jansson and Eduards 2016).

The concept of human security is shaped by the human being: the vital core that has to be protected. It is a deliberately protective idea of security (Kaldor 2007). In its original formulation, "human security" presents 
four main characteristics: the universality of threats, both in terms of types and territorial extension (unemployment, poverty, drugs, crime, terrorism, environmental pollution, human rights violations); the interdependence among its different components; prevention as crucial tool to achieve the goals; the centrality of the individual in satisfying the fundamental needs/rights. In other words, under the human security approach, the welfare of human beings around the world is the object of concern rather than the military and strategic interests of a State. The defense of human life is more important than the defense of States, and personal integrity is as important as territorial integrity. This orientation not only followed the pathway traced by the United Nations Charter, the development of international human rights law and the international machinery connected to it. It also tended to foster the development and implementation of policies which were devoted to meet the target of gender equality, placing focus on women's condition.

All this considered, human security had proven to be an attractive normative principle for feminists because it added a collective dimension to security, in particular for persons facing structural vulnerabilities, to the individual focus at the heart of the human rights discourse (Tripp 2013; Estrada-Tanck 2016). Moreover, both paradigms (feminism and human security) look at ways of empowerment that imply changes in the notion of existing social categories. However, if on the one hand, the human security approach has opened up conceptual ground for feminists to advance their concerns, both in theory and in practice, to address women's specific concerns, on the other hand, it was the feminist theory that contributed to the notion of human security by bringing gender into discussions linked to post-conflict, humanitarian affairs and security at the United Nations level (Hudson 2005).

As a matter of fact, the very concept of human security has undergone substantial review from a gender perspective. As generally-known, in its first systematic discussion on security, the UNDP did not dedicate any specific attention to women. Indeed, the Commission of Human Security Report had left out women as area of special concern, integrating instead gender-based inequality in all matters related to human security. According to Chenoy (2009), while human security rejected all forms of violence, this paradigm did not clearly demarcate what constitutes gender-specific violence, nor did it directly confront the ideologies and structures that oppress and deny justice and equity to women (Bunch 2004). By not paying attention to women as a subject, Bunch (2004) claims, key areas of women experience, such as violence against women in the family or reproductive rights, remained on the margins of the concept of human security. Moreover, by providing "special protection" to women and children, especially during times of acute insecurity (war, military occupation, conflict, economic collapse, famine, etc.), according to some feminists human security risked to dis-empower women, thus underlining their lack of agency (Chenoy 2009).

According to Tripp (2013), however, despite its many limitations, the concept of human security has become important enough in international policy-making to call for feminist attention (Basch 2004). More specifically, the feminist perspective has pointed out that an authentic understanding of security issues needs to be declined considering the specific women's security concerns. In not doing so, there is a concrete risk that the term "human" absorbs any gendered dimension within a gender (false) neutral approach and discourse to both human security and human rights. Including women as a category of identity within the security policy framework without integrating gender as a specific analytical unit can reinforce the dominance of the the so-called "universalism" based on a (false) neutral subject (human) as well as impede theoretical progress within security studies. The fact of considering women as a group conceals the differences existing among them and impedes to grasp the intersectional dimension of women's identities (Crenshaw 1989; Hudson 2005). A real awareness of diversity is fundamental to explain and understand how and why systems of domination originate and reproduce. Yet, this consideration does not nullify the universal dimension of different forms of oppression that interact with each others. A critical feminist perspective is equipped towards addressing the politics of multiple overlapping identities. Since gender is interlinked with other identity elements such as race, class and nationality, issues of universalism are overcome by connecting individual experiences to global structures, processes and conditions (Hudson 2005). A more articulated discourse on identity politics could help to clarify the ambivalence of human security as both a political project to promote women's rights and an analytical framework.

\section{The criminalization of violence against women in the international security discourse}

A watershed moment for the feminist movements had been the adoption by the United Nations Security Council of a number of resolutions on women, peace and security (WPS) ${ }^{2}$ (Butler, Mader, and Kean 2012; Cohn, Kinsella, and Gibbings 2004; Coomaraswamy 2015). In such context, the concept of human security was used by feminists groups to make gender mainstreaming relevant in the area of international security (Pettman 1992; True 2003; Walby 2005). Between 2000 and 2013, the United Nations Security Council has adopted seven resolutions which together are considered as the collective body of commitments to women, peace and security 
(Olonisakin, Barnes, and Ikpe 2011). The best known WPS resolution is 1325 (2000) which stresses the importance of women's equal and full participation as active agents in the prevention and resolution of conflicts, peace-building and peacekeeping, and calls for the increased protection of women during war and for the prosecution of crimes against women in armed conflict and during peace processes (Davies and True 2015).

While the two main strategies the corpus of WPS resolutions foresees to address women's security are the representation/participation of women in peace processes and the recognition of women's vulnerability, it has been said that the international community's response to women's insecurity during situation of conflict is focusing increasingly on the criminalization of (sexual) violence (Jansson and Eduards 2016; Baaz and Stern 2013; Engle 2014). Indeed, apart from Resolutions 1325 (2000), 1889 (2009) and 2122 (2013), which focus specifically on the roles of women in peace-building and on gender equality more in general, a number of women's peace activists have stressed that the others WPS resolutions, that is 1820 (2008), 1888 (2009), 1960 (2010), and 2106 (2013) place too much emphasis on women's victimization and the fight against impunity, mainly by strengthening both international and domestic criminal law frameworks. After the general call made in 1325 (2000), Resolution 1820 (2008) strongly reaffirmed the condemnation of all forms of sexual violence in armed conflicts and the importance of ensuring access to justice and assistance for victims. Resolution 1888 (2009) focuses on the inclusion of sexual violence issues in peace processes and addresses impunity; it also defines new mechanisms within the UN to intensify the struggle against war-related sexual violence, and foresees the establishment of a Special Representative of the Secretary General on the issue. Resolution 1960 (2010) establishes a monitoring, analysis and reporting mechanism on conflict-related sexual violence, and also calls on parties to armed conflict to make specific, time-bound commitments to prohibit and punish this category of crimes. In the end, Resolution 2106 (2013) reiterates its demand for the complete cessation, with immediate effect, by all parties to armed conflict, of all acts of sexual violence and it calls on these parties to make and implement specific time-bound commitments to combat sexual violence focusing on accountability for perpetrators. It also represents the first time that United Nations Security Council on gender, peace and security mentions male survivors of sexual gender based violence.

According to some scholars, WPS resolutions present women as a group particularly exposed to violence whose vulnerability seems to stem exclusively from their sexual difference and from conflict situations. Rather than agents of peace (Charlesworth 2008), women seem to be left with a single option: to become the victims protected by someone else (Jansson and Eduards 2016). In the context of addressing women's insecurity, the Security Council, instead of attributing an agency that enables them to tackle the violence, employed a helpless and sexualized representation of women, without questioning the inevitability of their assumed powerlessness (Otto 2009; Shepherd 2008b). Rather than stating, as if it were a fact, that "violence, intimidation and discrimination ... erode women's capacity and legitimacy to participate in post-conflict public life", the Security Council could have tried to debunk the myth of women's helplessness to enable them to face sexual aggression and the myths that lead to the stigmatization and ostracism of those women who have survived sexual violence (Engle 2014; Cunniff Gilson 2016).

Greater focus on the criminalization of sexual violence does not seem to be balanced by the "participation component" of WPS resolutions. In this regard, while one corollary of the women, gender and security discourse is participation, the "sexual violence component" of WPS resolutions have been given more energy and time from the Security Council and its subsidiary organs (Heathcote 2014). In addition, while representing an acknowledgment of women's role in decision-making fora and processes that for long formally precluded them, the "participation component" has also been subject to increasing criticism. More specifically, some feminist scholars claim that it contains a partial understanding of women's subjectivity that risk gender and cultural essentialism (Heathcote 2014; Tickner and Sjoberg 2011). Indeed, not only do WPS resolutions assume that women are more peaceful than men, but also that women have common traits, interests and needs and constitute a homogeneous group (Jansson and Eduards 2016; Heathcote 2014). The failure to address women's diversity due to the intersection of gender with other vectors of privilege and marginalization is coupled with the invisibility of men built on the assumption that they all already have access to decision-making fora. Moreover, according to Heathcote (2014), in the WPS resolutions, women represent only women. In the resolution dealing with sexual violence, for example, women's participation in peace negotiations or peace missions is functional to facilitate the fight against sexual violence. In this framework, the rationale of women's participation is the protection of other "more vulnerable" women, rather than to increase women's empowerment.

In conclusion, if the search for a balance between victimization and empowerment manifests the international community's attempts to increase the legitimacy of international police interventions in the contexts of armed conflicts with reference to both the composition of civilian and military contingencies and their mandate, the participation component of WPS, rather than transforming gender relations, aims at merely counting women within the operational and political mechanisms governing these situations (Cockburn and Zarkov 2002). 


\section{The criminalization of violence against women under international human rights and criminal law}

In recent decades, international human rights law has significantly developed. The expansion of this branch of public international law has interested not only issues related to the their universality, but also the processes of multiplication and specification of all those needs, those instances and situations that have led to the progressive recognition of other rights. At the same time, however, the limits of these rules to be accepted as binding as well as the resistance of many States to assume human rights as a paradigm for domestic law and policies continue to pose challenging questions about justice, both for individual and international communities.

The process of multiplication and specification of human rights is related to the growing number of conditions considered as deserving legal protection and to widening the ownership of certain rights to subjects that cannot be assimilated to a generic "man". The impossibility to consider the individual as a generic entity has obliged international law-makers to look at the specificity of different modes of being and of being into society (Otto 2009; Chalresworth and Chinkin 2000). It is within this scenario that women's human rights and the related issue of women's protection from violence or, more properly framed, women's right to live free from violence, should be understood.

Under international law, references to violence against women are closely anchored to the notion of discrimination or, more practically, to the full recognition of the substantive dimension of the principle of equality on the ground of sex (Peters and Wolper 1995; Lacey 2004). Still, to date, a concrete translation of the latter has not been sufficiently outlined. This is mainly due to the fact that human rights standards provide far more established rules for the protection of individuals from discrimination arising from specific violations, rather than promoting measures that eliminate structural differences between men and women (Estrada-Tanck 2016; Edwards 2010).

Women's rights are based on concrete historical experience, but unlike what happens to men, the violations which they are victims of are often inadequately dealt with (at least in terms of the gravity of situations that women live) from the legal perspective. This is especially true when trying to claim such rights and, more in general, considering the issue of human rights justiciability. As a matter of fact, for a long time many countries did not consider abusive behavior against women as a human rights violation. Violent acts against women were therefore neither considered relevant under criminal law, nor were they considered social facts worthy of consideration, and in any case, not to the degree of significance and complexity that such situations would have required and still require.

Considering violence against women as an act of injustice rather than "normal" if not "natural", in the sense of belonging to the "physiology of relationships between men and women" or constituting an essential component of the way man "treats" women, has led to a progressive awareness of the socially constructed and unnatural character of this phenomenon. Consequently, the tools developed to redress violence against women are mostly normative and political in nature (Sally 2003). This scenario, at least on a formal level, implies the end of the gender-neutral character of national criminal systems and consequently, at least in some contexts, the end of impunity for severe crimes and abuses committed against women every day.

After centuries during which States consented female domesticity and the gratuity of care work, thus contributing to building a history of denial of women's most fundamental rights, today national governments, no longer able to elude direct responsibility for the protection of women's human rights, attempt to fight against this phenomenon by means of criminal law. Over the past decades, such trend has favored the adoption by international and national institutions of strategies that would privilege the criminalization of violence against women (Randall and Venkatesh 2015). At Vienna's World Human Rights Conference of 1993 the international community announced its commitment to fight violence against women, coming up its first concrete expression, in 1993, with the United Nations Declaration on the Elimination of Violence Against Women (DEVAW). ${ }^{3}$ The DEVAW specifies that United Nations members have a duty to exercise "due diligence to ... punish acts of violence against women" even if those acts are perpetrated by private persons. The duty to criminalize and therefore punish abusive behaviors against women was then emphasized in the 1995 Beijing Declaration and Platform for Action, adopted by 189 UN Member States, which further recognizes that violence against women demands that states enact or reinforce sanctions that punish perpetrators and provide women with access to justice. $^{4}$

Beyond these non-binding declarations, violence against women could be said to breach a number of international or regional human rights treaties that require States to criminalize certain conducts corresponding to acts, practices or behaviors that are detrimental to women. In particular, the criminalization of violence against women in all its forms has long been recognized by the Committee on the Elimination of All Forms of Discrimination Against Women in General Recommendation $\mathrm{n} .12$ and $19,{ }^{5}$ by the UN Special Rapporteurs on violence against women in many reports, ${ }^{6}$ and several UN bodies as an essential tool to combat discrimination against 
women. ${ }^{7}$ A 2006 Report on violence against women by the Secretary General reiterates the due diligence obligation of States under the Beijing Platform "to treat all forms of violence against women and girls as criminal offences" (Benninger-Budel 2008). ${ }^{8}$ In 2013, the annual report of the UN Special Rapporteur on Violence Against Women focused on state responsibility to eliminate violence against women. ${ }^{9}$

At the regional level, the Inter-American Commission on Human Rights (IACHR) has consistently demanded that states adopt "criminal, civil and administrative laws to prevent, punish and eradicate violence against women" (McQuigg 2012). Both the Council of Europe and the European Union have reiterated that violence against women is a form of discrimination that requires adequate criminal remedies. The Council of Europe Convention on Preventing and Combating Violence against Women and Domestic Violence (Istanbul Convention) ${ }_{1}^{10}$ which entered into force in August 2014, explicitly obliges its parties to criminalize violent acts against women (McQuigg 2017). The European Convention of Human Rights, ${ }^{11}$ while not explicitly prohibiting violence against women, has been consistently interpreted by the European Court of Human Rights as imposing many substantive and procedural obligations on States Parties. The standard of due diligence developed by the Strasbourg Court regarding cases of violence against women has been consistently interpreted as requiring States to put in place an effective legislative framework that enables criminal prosecutions of individuals (Edwards 2010; Hasselbacher 2010; Pividori 2016).

Beyond human rights law, the trend towards the criminalization of male violence against women has involved also other branches of international law. The crimes committed in the Balkans and in Rwanda in the 1990s have led to a radical change in the way war-related abuses against women are considered, and to formal acknowledgement of the need to sanction such crimes and punish its perpetrators (De Brouwer 2013). Following such events, the issue of violence against women in international humanitarian and criminal law has assumed a whole new relevance, starting with the investigation work first conducted by United Nations Commission 780 (Niarchos 1995) and subsequently by the Prosecutor's Office of the International Criminal Tribunal for the Former Yugoslavia and Rwanda. As a result, acts of violence against women have no longer been regarded as marginal corollaries of a conflict, but rather as behaviors with autonomous criminal relevance under international law (Stiglmayer 1994).

While the statutes of the International Criminal Tribunal for the former Yugoslavia (ICTY) and the International Criminal Tribunal for Rwanda (ICTR) both included rape as a crime against humanity, with the adoption in 2002 of the Rome Statute establishing the International Criminal Court, the list of prohibited sexual and gender-based international crimes has significantly expanded. The Rome Statute is the first instrument in international law to illustrate the list of war crimes related both to international and non-international armed conflicts (Halley 2008). The Statute has also expanded the list of sexual and gender-based crimes as crimes against humanity to include not only rape, but also sexual slavery, enforced prostitution, forced pregnancy, enforced sterilization, and other forms of sexual violence, as well as persecution based on gender. Sexual and gender-based crimes committed with intent to destroy, in whole or in part, a national, ethnic, racial, or religious group may also constitute acts of genocide. In 2012, the effective investigation and prosecution of sexual and gender-based crimes was elevated by the Office of the Prosecutor (OTP) to become one of its key strategic goals. During the same year the Prosecutor appointed a Special Adviser on Gender and in June 2014 a Policy Paper on Sexual and Gender-Based Crimes was adopted. ${ }^{12}$ In this document, the OPT recognizes that sexual and genderbased crimes are amongst the gravest under the Statute and commits to integrating a gender perspective and analysis into all its work.

Undoubtedly, the recourse to criminal law solutions has created the conditions to put real and symbolic expectations in the domestic and international criminal response to violence against women as well as for the protection of victims. However, such expectations have implied, on the one hand, a precise and rigid definition of acts of violence, on the other, the strengthening of individualization - inevitable in the discourse of criminal liability. While the focus on criminalization tends to emphasize the extent of social disvalue of violence against women, it also partly overshadows the endemic dimension and socio-cultural context that is at the root of such phenomenon. Indeed, one of the critique levelled at the existing due diligence standard is that it focuses primarily on violence against women as an isolated act and fails to take into consideration the structural inequalities and the complex and intersecting relations of power in the public and private spheres of life that lie at the heart of sex discrimination (Pividori 2016). In other words, the criminal response to violence against women risks obfuscating the broader framework of affliction and subjugation within which violence manifests itself in the forms and proportions that many researchers today have highlighted.

In conclusion, it could be said that this trend is inevitably accompanied by a great emphasis on women's victimization. Indeed, both the legal and policy instruments developed at the international level, by privileging criminal justice solutions, have put emphasis on the passivity or on the vulnerability of women as subjects that need to be protected, without however, creating the conditions to prevent violence (Kapur 2002; Mahoney 1994). These efforts towards a reinforcement of the punitive/criminal individual solution have been institutionalized in law and policy achieving significant changes in the statutes, the organization of investigative and 
prosecutorial agencies, and the allocation of court services and resources. The discourses related to the right to a remedy and/or women's active participation in paths towards the restoration of "normal" life only partially mitigate the narrow focus of accountability strategies.

\section{The merits and limits of criminalizing male violence against women}

As shown, international legal and policy frameworks are increasingly turning to criminal law enforcement solutions to the issue of violence against women. At the same time, however, the use of criminal law to combat such violence has become a subject of controversy for many reasons. While some feminists' opposition to criminalizing gender-based violence can be traced to broader skepticism about legal approaches to violence (Klugman 2017), the strategy of criminalizing violence against women is questioned on the account that domestic and international criminal law is presented as the main solution to an issue that cannot be reduced to the victim-offender relationship.

The current legitimacy and progressive relevance, both at the material and symbolic level, of criminal law in the debates regarding male violence against women are undoubtedly a concrete manifestation of the response provided by States and, in recent years, also by intergovernmental organizations to the demand for an extension, of both civil and social rights, brought by a whole series of collective actors between the late 1960s and the early 1980s (Belknap 2007). Among them, the feminist movement which strived to put an end to man's power over women by criticizing family and reproductive patterns and by deconstructing the "neutrality" of legal norms (Walby, Armstrong, and Sofia 2010).

This critical analysis and the political proposal expressed by women's movements have been addressed in the human rights and international relations discourse, identifying, even beyond the State, areas in which the notion of security does not consider the structure of gender relations and the role of patriarchate. Hence, the struggle against violence is pivotal, due to the dramatic nature of situations that characterize it and its symbolic significance in recognizing the needs and the identity of women in terms of dignity and rights.

Over the years, a lower threshold of what is conceived as violent, offensive, unacceptable, discriminatory, serious, has certainly gained public recognition so that women could develop a different attitude towards criminal justice. A debate, over the past two decades, on the potential of human rights as a tool to promote the status of women has paved the way for policies that are inspired by the principles of freedom and substantive equality. They have been functional in helping to eliminate oppressive and discriminatory behaviors. This involved systematic work to integrate the gender dimension in any policy-making process aimed at developing tools for the protection of women's human rights. This requires interpretative efforts that move away from a gender-neutral perspective. At the same time, to gather the various academic and feminist analytical positions on the goals of recognizing the political nature of the private dimension, and the need not to reduce gender relations simply to a problem of the integration of women.

This process has undoubtedly contributed to criminal justice responses, and the definition of new areas of victimization (Buzawa and Buzawa 2003). This has accentuated the symbolic relevance of criminalization without, however, placing adequate attention to the implementation of devices aimed at protecting victims as provided by the standards set forth in supranational binding and non-binding instruments.

It is important to note that the criminalization of a given behavior indicates a specific orientation in elaborating and representing a particular issue. As well summarized by Pitch (1989), the criminalization of certain acts and situations implies a conceptual and cognitive revision of the same, resulting in the creation of new knowledge about that act and those situations and of course, a reconsideration, both at the material and axiological level, of acceptance/social rejection of certain conducts. If the trend is criminalization, it is important to consider the intrinsic rigidity that characterizes the system of criminal law as well as its implicit limits in grasping or tackling the structural nature or the social implications of given behaviors. In other words, it is obvious that the way in which a given issue is constructed, posed, and represented is inevitably related to the type of solution that is being proposed.

The criminalization of violence against women, in creating a relationship between the two categories of subjects, the victims and the perpetrators, while not eliding the complexity of the problem, partially downsizes its political dimension. It does so because criminalization inevitably requires the "individualization" of the conflict. The fact that criminal liability is personal implies that the latter can be attributed to an identifiable subject. As a consequence, the broader social context and the structural dimension within which the specific act of violence took place, and with it the related State responsibility for that context to exist, risks being overshadowed. A partially different consideration could be made for international criminal law. This is due to the potential attitude of this normative system to capture a larger spectrum of severe and widespread violations based on gender as well as for its political and symbolic meanings. Indeed, the requirement to prove a specific 
contextual element (i. e. the existence of an armed conflict for war crimes or a widespread and systematic attack against a civilian population for crimes against humanity), while not per se guaranteeing the capacity to properly frame abuses against women as behaviors embedded in unequal gender power relations, may correspond to an enhanced capacity to grasp the systemic and pervasive nature of certain abuses against women.

In concrete terms, another effect of the greater institutional attention with respect to the criminal justice response to violence against women, and therefore the progressive affirmation of punitive options, has been the overall simplification of the phenomenon of male violence against women. In this sense, violence against women is not only the result of well rooted processes of discrimination and inequality, but it is also emblematic of the difficulties States have in countering the phenomenon. The risk could be that, beyond those cases under prosecution, States are no longer able to properly understand the phenomenon. This is true especially in cases where no serious monitoring activity was set up to observe, from the quantitative perspective, the trends and evolution with regards to its manifestation, the environment within which it developed, and the profiles of those affected by it.

While the recognition of male criminal accountability marks the end of States' failure to assume a direct role in protecting women against violence, it is equally important to understand that recourse to repressive instruments is a limited tool in addressing what is a social, political, and economic problem (Bailey 2010). Indeed, not only is it ineffective with regards to the protection of the victims of violence, but it also inadequate with regard to the need to rethink the phenomenon, starting from a proper analysis of the reasons why violence, for many women, is an ordinary component of their lives. Without considering that, in general, this approach is totally inadequate with respect to the prevention of violence. Indeed, both domestic and international criminal law are more reactive (punitive) rather than preventive tools.

As a matter of fact, the capacity of women's movements engaged in the struggle against violence to interpret the strategy of criminalization have enabled a shift towards seeing violence as a social and public problem. New definitions of consciousness and conscience have developed, both at the individual and collective level. This has undoubtedly pushed for political accountability and the inclusion of violence against women on the agenda at various levels of decision-making, so that States can no longer postpone setting up systems of intervention aimed at the prevention, repression, protection and remedy along a continuum that goes beyond the single offence, to invest the problem of violence in its complexity and with it, more extensively, the fight against sex based discrimination.

The emphasis on the legal approach to violence against women inevitably focuses on the criminal response to abusive behaviors. Although this represents a fundamental step in framing male violence against women as a serious violation of individual rights, it also needs to be framed within a more holistic political and legislative scenario. In particular, the importance of tackling the root that causes structural inequalities that lead to violence needs to be focused on, overcoming patriarchal and masculine institutions and cultures.

\section{Conclusions}

After the above considerations, it is almost inevitable to question to what extent victimization as a strategy to deal with women victims of violence is, on the one hand, an option bound to the "judicial path", or even more to the normative processes within and beyond the paradigm of human rights; or, on the other hand, a way to respond - albeit totally inadequately - to the systematic impunity which has always characterized violence itself along with the generalizations with which it has always been analyzed and addressed (Schneider 1993).

Obviously, violence against women can only be understood if it is contextualized within a patriarchal society and recognized for its specificity compared with other forms of violence. What is missing in the progressive regulatory process on violence against women, in times of peace and conflict, is the dimension of genuine listening and sharing real women's experiences (Sanders 2002). A narrative that considers not only the survival of violence, but also the resistance of women. In other words, it is difficult to find in the domestic judicial responses to violence (but, to a certain extent, also international ones) a space for genuine forms of development of a feminist approach to (un)justice that considers structural injustices rather than the individual's. Authentic stories rather than procedural truths.

The justice that women victims of violence demand must necessarily go through a political re-elaboration of the economic and social contexts that are at the origin of (social) mechanisms that feed and legitimize violence. It is not just about adding a gender dimension to judicial processes, it is about giving voice, outside criminal trials, to women who are subjected to discrimination and abuse, as well as to consider taking on political responsibilities as a key step in the fight against violence. As a consequence, the dimension of prevention crosses that of protection until they fully overlap. 
The structural dimension of violence is increasingly evident. Therefore, it is more and more urgent to develop policy tools that go beyond the emergency phase. Violence against women needs a feminist perspective. Bringing sex/gender to the forefront in the discourse on inequalities would also be a fundamental step in building a judicial response to violence that is more adherent to women's needs. Gender equality and an understanding of its implications in a broad range of policy fields could potentially offer new opportunities to promote women's human rights and frame the debate towards new public policy practices such as gender mainstreaming in the framework of intersecting inequalities and humanitarian crisis.

\section{Notes}

1 The 1994 Human Development Report defined human security as people's "safety from chronic threats and protection from sudden hurtful disruptions in the patterns of daily life." Seven types of security were listed as components of human security: economic security; food security; health security; environmental security; personal (physical) security; community security; and political security.

2 UNSC (UN Security Council). 2000. Resolution 1325 On Women, Peace and Security; UNSC (UN Security Council). 2008. Resolution 1820 On Women, Peace and Security; UNSC (UN Security Council). 2009. Resolution 1888 On Women, Peace and Security; UNSC (UN Security Council). 2009. Resolution 1889 On Women, Peace and Security; UNSC (UN Security Council). 2010. Resolution 1960 On Women, Peace and Security; UNSC (UN Security Council). 2013. Resolution 2106 On Women, Peace and Security; UNSC (UN Security Council). 2013. Resolution 2122 On Women, Peace and Security.

3 In the Preamble of the DEVAW, violence is explicitly recognized as a manifestation of historically unequal power relations between men and women which have led to discrimination against women by men, and more precisely, is one of the crucial social mechanisms by which women are forced into a subordinate position compared with men. According to the text of DEVAW, violence includes physical, sexual and psychological violence, and ranges over such violent acts or behaviors as beating, spouse rape, genital mutilations and other practices harmful to women, dowry-related violence, violence linked to exploitation, workplace molestation, trafficking of women, and forced prostitution.

4 A/CONF.157/23, World Conference on Human Rights, Vienna, June 14-25, 1993; A/CONF.177/20/Rev.1, Fourth World Conference on Women, Beijing, September 4-15, 1995.

5 Committee on the Elimination of Discrimination Against Women, General Recommendation No. 12, UN Doc. A/44/38 (1989); Committee on the Elimination of Discrimination Against Women, General Recommendation 19, UN Doc. A/47/38 (29th January 1992).

6 Yakin Ertürk, Special Rapporteur on violence against women, its causes and consequences, "The Due Diligence Standard as a Tool for the Elimination of Violence against Women", UN Doc. E/CN.4/2006/61 (20th January 2006); Yakin Ertürk, Special Rapporteur on violence against women, its causes and consequences, "Indicators on violence against women and State response", UN Doc. A/HRC/7/6 (29th January 2008); Rashida Manjoo, Special Rapporteur on violence against women, its causes and consequences, UN Doc. A/HRC/14/22 (19th April 2010).

7 UN Human Rights Committee, General Comment No. 28, "Equality of Rights Between Men and Women (Article 3)", UN Doc. CCPR/C/21/Rev.1/Add.10 (2000); UN Human Rights Committee, "General Comment 35 (Article 9)", UN Doc. CCPR/C/GC/35 (16th December 2014); UN Committee against Torture, “General Comment 2 (Article 2)”, UN Doc. CAT/C/GC/2/CRP.1/Rev.4 (2007); UN Committee on Economic, Social and Cultural Rights, "General Comment 16", UN Doc. E/C.12/2005/4 (11th August 2005).

8 A/61/122/Add.1, 6th July 2006, "Secretary Report. In-depth study on all forms of violence against women".

9 Rashida Manjoo, Special Rapporteur on violence against women, its causes and consequences, "State Responsibility for Eliminating Violence against women", UN Doc. A/HRC/23/49 (14th May 2013).

10 Council of Europe, Convention on Preventing and Combating Violence Against Women and Domestic Violence, 11th May 2011, C.E.T.S. No. 210.

11 Council of Europe Convention for the Protection of Human Rights and Fundamental Freedoms, 4th November 1950, C.E.T.S. No. 005. 12 International Criminal Court (2014), Office of the Prosecutor, Policy Paper on Sexual and Gender-Based Crimes, https://www.icccpi.int/iccdocs/otp/OTP-Policy-Paper-on-Sexual-and-Gender-Based-Crimes-June-2014.pdf.

\section{References}

Armstrong, ]., S. Walby, and S. Strid. 2009. The Gendered Division of Labour: How Can We Assess the Quality of Employment and Care Policy from a Gender Equality Perspective? Benefits: Journal of Poverty and Social Justice 17 (3):263-275.

Baaz, M. E., and M. Stern. 2013. Sexual Violence as a Weapon of War? Perceptions, Prescriptions, Problems in the Congo and Beyond. New York: Zed Book.

Bailey, K. D. 2010. Lost in Translation: Domestic Violence, the Personal Is Political, and the Criminal Justice System. Journal of Criminal Law and Criminology 100 (4):1255-1300.

Basch, L. 2004. Human Security, Globalization, and Feminist Visions. Peace Review 16 (1):5-12.

Baxter, S., and M. Lansing. 1980. Women and Politics: The Invisible Majority. Ann Arbor: University of Michigan Press.

Belknap, J. 2007. The Invisible Woman: Cender, Crime, and Justice. Belmont, CA: Wadsworth.

Benninger-Budel, C. 2008. Due Diligence and Its Application to Protect Women from Violence. Leiden: Brill.

Bethke, E. J., and S. Tobias, eds.1990. Women, Militarism and War. Savage: MD Rowman \& Littlefield.

Boserup, E. 1970. Women's Role in Economic Development. New York: Saint Martin's.

Brock-Utne, B. 1989. Feminist Perspectives of Peace and Peace Education. New York: Columbia Teachers College.

Bunch, C. 1990. Women's Rights as Human Rights: Toward a Re-Vision of Human Rights. Human Rights Quarterly 12 (4):486-498.

Bunch, C. 2004. A Feminist Human Rights Lens. Peace Review 16 (1):29-34. 
Bunch, C., and N. Reilly. 1994. Demanding Accountability: The Clobal Campaign and Vienna Tribunal for Women's Human Rights. New Brunswick, N]: Center for Women's Global Leadership.

Butler, M., K. Mader, and R. Kean. 2012. “Women, Peace and Security Handbook.” Peace Women Project, WILPF. Accessed September 7, 2017. http://wilpf.org/wp-content/uploads/2014/07/women_peace_and_security_handbook__second_edition.pdf.

Buzawa, E. S., and C. G. Buzawa. 2003. Domestic Violence: The Criminal Justice Response. London: Sage.

Chalresworth, H., and C. Chinkin. 2000. The Boundaries of International Law: A Feminist Analysis. Manchester: Manchester University Press. Charlesworth, H. 2008. Are Women Peaceful? Reflections on the Role of Women in Peace-Building. Feminist Legal Studies 16 (3):347-361. Charlesworth, H., C. Chinkin, and S. Wright. 1991. Feminist Approaches to International Law. American Journal of International Law 85 (4):613-645.

Chenoy, Anuradha M. 2009. “The Gender and Human Security Debate." IDS Bulletin 40 (2): 44-49.10.1111/j.1759-5436.2009.00021.x. Cockburn, C., and D. Zarkov, eds.2002. The Post-War Moment: Militaries, Masculinities and International Peacekeeping. Bosnia and the Netherlands. London: Lawrence \& Wishart.

Cohn, C., H. Kinsella, and S. Cibbings. 2004. Women, Peace and Security Resolution 1325. International Feminist Journal of Politics 6 (1):130-140. Coomaraswamy, R. 2015 Preventing Conflict, Transforming Justice, Securing the Peace: A Clobal Study on the Implementation of United Nations Security Council resolution 1325 (UN Women), Accessed September 7, 2017. http://wps.unwomen.org/.

Crenshaw, K. 1989. Demarginalizing the Intersection of Race and Sex: A Black Feminist Critique of Antidiscrimination Doctrine, Feminist Theory and Antiracist Politics. University of Chicago Legal Forum 140:139-167.

Cunniff Gilson, E. 2016. Vulnerability and Victimization: Rethinking Key Concepts in Feminist Discourses on Sexual Violence. Signs: Journal of Women in Culture and Society 42 (1):71-98.

Davies, S. E., and J. True. 2015. Reframing Conflict-Related Sexual and Gender-Based Violence: Bringing Gender Analysis Back In. Security Dialogue 46 (6):495-512.

De Brouwer, A.-M., etal., eds. 2013. Sexual Violence as an International Crime: Interdisciplinary Approaches. Cambridge: Intersentia.

Degani, P. 2014. Cender Security between Human Development and Human Security. Recent Issues in the Political International Agenda. La Camera Blu. Rivista Di Studi Di Cenere 10:1-20.

Edwards, A. 2010. Violence against Women under International Human Rights Law. Oxford: Oxford University Press.

Elshtain, J. B. 1987. Women and War. New York: Basic Books.

Engle, K. 2014. The Grip of Sexual Violence: Reading UN Security Council Resolution on Human Security. In Rethinking Peacekeeping, Gender Equality and Collective Security, edited by H. Gina and O. Diane, 23-47. Basingstoke: Palgrave MacMillian.

Enloe, C. 1993. The Morning After: Sexual Politics and the End of the Cold War. Berkeley: University of California Press.

Enloe, C. 2000. Maneuvers: The International Politics of Militarising Women's Lives. Berkeley: University of California Press.

Enloe, C. 2007. Clobalization \& Militarism: Feminists Make the Link. Lanham: Rowman \& Littlefield.

Estrada-Tanck, D. 2016. Human Security and Human Rights under International Law. The Protections Offered to Persons Confronting Structural Vulnerability. Oxford: Hart Publishing.

Fineman, M. 2008. The Vulnerable Subject: Anchoring Equality in the Human Condition. Yale Journal of Law and Feminism 20 (1):1-23.

Giles, W. 2004. The Continuum of Violence. A Cender Perspective on War and Peace. In Sites of Violence: Cender and Conflict Zones, edited by W. Giles and J. Hyndman, 24-44. Berkeley: University of California Press.

Coldstein, J. S. 2001. War and Cender. How Cender Shapes the War System and Vice Versa. Cambridge: Cambridge University Press.

Halley, J. 2008. Rape at Rome: Feminist Interventions in the Criminalization of Sex-Related Violence in Positive International Law. Michigan Journal of International Law 30:1-123.

Hasselbacher, L. 2010. State Obligations regarding Domestic Violence: The European Court of Human Rights, Due Diligence, and International Legal Minimums of Protection. Northwestern Journal of International Human Rights 8 (2):190-215.

Heathcote, G. 2014. Participation, Gender and Security. In Rethinking Peacekeeping, Cender Equality and Collective Security, edited by H. Gina and D. Otto, 48-69. Basingstoke: Palgrave MacMillian.

Hudson, H. 2005. Doing' Security as though Humans Matter: A Feminist Perspective on Cender and the Politics of Human Security. Security Dialogue 36 (2):155-174.

Jansson, M., and M. Eduards. 2016. "The Politics of Cender in the UN Security Council Resolutions on Women, Peace and Security." International Feminist Journal of Politics 18 (4): 1-15.

Kaldor, M. 2007. Human Security: Reflections on Clobalization and Intervention. Cambridge: Polity Press.

Kapur, R. 2002. The Tragedy of Victimization Rhetoric: Resurrecting the Native Subject in International/Postcolonial Feminist Legal Politics. Harvard Human Rights Law Journal 15 (1):1-37.

Kehoane, R. 1989. International Relations Theory: Contributions of a Feminist Standpoint. Millennium - Journal of International Studies 18 (2):245-253.

Kirby, P., and L. J. Shepard. 2016. The Futures past of the Women, Peace and Security Agenda. International Affairs 92 (2):373-392.

Klugman, J. 2017. “Cender Based Violence and the Law.” Background paper for World Development Report 2017, Accessed September 7, 2017. http://pubdocs.worldbank.org/en/232551485539744935/WDR17-BP-Cender-based-violence-and-the-law.pdf.

Lacey, N. 2004. Feminist Legal Theory and the Rights of Women. In Gender and Human Rights, edited by K. Karen, 13-56. Oxford: Oxford University Press.

Mahoney, M. 1994. Victimization or Oppression? Women's Lives, Violence and Agency. In The Public Nature of Private Violence: The Discovery of Domestic Abuse, edited by F. M. Albertson and M. Roxanne, 59-92. New York: Routledge.

McQuigg, R. 2012. Domestic Violence and the Inter-American Commission on Human Rights: Jessica Lenahan (Gonzales) V United States. Human Rights Law Review 12 (1):122-134.

McQuigg, R. 2017. The Istanbul Convention, Domestic Violence and Human Rights. Abingdon: Routledge.

Niarchos, C. 1995. Women, War and Rape: Challenges Facing the International Tribunal for the Former Yugoslavia. Human Rights Quarterly 17 (4):649-690.

Olonisakin, F., K. Barnes, and E. Ikpe. 2011. Women, Peace and Security: Translating Policy into Practice. London: Routledge. 
Otto, D. 2009. The Exile of Inclusion: Reflections on Cender Issues in International Law over the Last Decade. Melbourne Journal of International Law 10 (1):11-25.

Peters, J., and A. Wolper, eds.1995. Women's Rights, Human Rights: International Feminist Perspectives. New York: Routledge.

Pettman, J. J. 1992. A Feminist Perspective on Peace and Security. Interdisciplinary Peace Research 4 (2):58-71.

Pickup, F., S. Williams, and C. Sweetman. 2001. Ending Violence against Women: A Challenge for Development and Humanitarian Work. Oxford: Oxfam Publishing.

Pitch, T. 1989. Responsabilità Limitate. Attori, Conflitti, Giustizia Penale. Milano: Feltrinelli.

Pividori, C. 2016. Dieci Anni Di Violenza Domestica Alla Corte Di Strasburgo. Sud Europa 2:15-30.

Radačić, I. 2007. Human Rights of Women and the Public/Private Divide in International Human Rights Law. Cyelp 3:443-468.

Randall, M., and V. Venkatesh. 2015. Criminalizing Sexual Violence against Women in Intimate Relationships: State Obligations under Human Rights Law. American Journal of International Law Unbound 109:189-196.

Reardon, B. 1985. Sexism and War System. New York: Teachers College Press.

Sally, E. M. 2003. Constructing a Clobal Law-Violence against Women and the Human Rights System. Law \& Social Inquiry 28 (4):941-977.

Sanders, A. 2002. Victims Participation in an Exclusionary Criminal Justice System. In New Vision of Crime Victims, edited by H. Caroline and Y. Richard. Oxford: Hart Publishing.

Schneider, E. M. 1993. Feminism and the False Dichotomy of Victimization and Agency. New York Law School Law Review 38:387-399.

Shepherd, L. J. 2008a. Cender, Violence \& Security: Discourse as Practice. London: Zed Books.

Shepherd, L. J. 2008b. Power and Authority in the Production of United Nations Security Council Resolution 1325. International Studies Quarterly 52:383-404.

Shepherd, L. J. 2010. Cender Matters in Clobal Politics: A Feminist Introduction to International Relations. London: Routledge.

Sjoberg, L. 2006. Cendered Realities of the Immunity Principle: Why Cender Analysis Needs Feminism. International Studies Quarterly 50 (4):889-910.

Sjoberg, L. 2009. Introduction to Security Studies: Feminist Contributions. Security Studies 18 (2):183-213.

Steans, J. 1998. Gender and International Relations: An Introduction. Cambridge: Polity Press.

Stiglmayer, A., ed.1994. Mass Rape, the War against Women in Bosnia-Herzegovina. Lincoln: University of Nebraska Press.

Sullivan, D. 1995. The Public/Private Distinction in International Human Rights Law. In Women's Rights, Human Rights: International Feminist Perspectives, edited by P. Julie and W. Andrea, 126-134. New York: Routledge.

Tickner, J. A. 1988. Hans Morgenthau's Principles of Political Realism: A Feminist Reformulation. Millennium: Journal of International Studies 17 (3):429-440.

Tickner, ]. A. 1992. Cender in International Relations: Feminist Perspectives on Achieving Cender Security. New York: Columbia University Press. Tickner, J. A. 1995. Introducing Feminist Perspectives into Peace and World Security Courses. Women's Studies Quarterly 23 (3/4):48-57.

Tickner, ]. A. 2001. Cendering World Politics: Issues and Approaches in the Post-Cold War Era. New York: Columbia University Press.

Tickner, J. A., and L. Sjoberg. 2011. Conclusion: Looking Forward for Feminist International Relations. In Feminism and International Relations: Conversations about the Past, Present and Future, edited by J. A. Tickner and L. Sjoberg, 221-236. New York: Routledge.

Tripp, A. M. 2013. Toward a Cender Perspective on Human Security. In Cender, Violence and Human Security. Critical Feminist Perspectives, edited by T. A. Mari, F. M. Marx, and E. Christina, 3-32. New York and London: New York University Press.

True, J. 2003. Mainstreaming Cender in Clobal Public Policy. International Feminist Journal of Politics 5 (3):368-396.

Verloo, M., ed.2007. Multiple Meanings of Cender Equality. A Critical Frame Analysis of Cender Policies in Europe. Budapest: CEU Press.

Walby, S. 2005. Cender Mainstreaming: Productive Tensions in Theory and Practice. Social Politics 12 (3):321-343.

Walby, S., J. Armstrong, and S. Sofia. 2010. Physical and Legal Security in the Criminal Justice System: A Review of Inequalities. Manchester: Equality and Human Rights Commission.

Whitworth, S. 2004. Men, Militarism and UN Peacekeeping. A Gendered Analysis. London: Lynne Rienner Publishers.

Youngs, G. 2008. From Practice to Theory: Feminist International Relations and 'Cender Mainstreaming'. International Politics 45:688-702.

Yuval-Davis, N. 2008. Gender and Nation. London: Sage. 